\title{
Separation of Gas Mixtures by Supported Complexes
}

D. A. Nelson

M. A. Lilga

December 1986

Prepared for the U.S. Department of Energy under Contract DE-AC06-76RLO 1830

Pacific Northwest Laboratory

Operated for the U.S. Department of Energy

by Battelle Memorial Institute 


\title{
DISCLAIMER
}

This report was prepared as an account of work sponsored by an agency of the United States Government. Neither the United States Government nor any agency thereof, nor Battelle Memorial Institute, nor any of their employees, makes any warranty, expressed or implied, or assumes any legal liability or responsibility for the accuracy, completeness, or usefulness of any information, apparatus, product, or process disclosed, or represents that its use would not infringe privately owned rights. Reference herein to any specific commercial product, process, or service by trade name, trademark, manufacturer, or otherwise, does not necessarily constitute or imply its endorsement, recommendation, or favoring by the United States Government of any agency thereof, or Battelle Memorial Institute. The views and opinions of authors expressed herein do not necessarly state or reflect those of the United States Government or any agency thereof, or Battelle Memorial Institute.

\author{
PACIFIC NORTHWEST LABORATORY \\ operated by \\ BATTELLE \\ for the \\ UNITED STATES DEPARTMENT OF ENERGY \\ under Contract DE-AC06-76RLO 1830
}

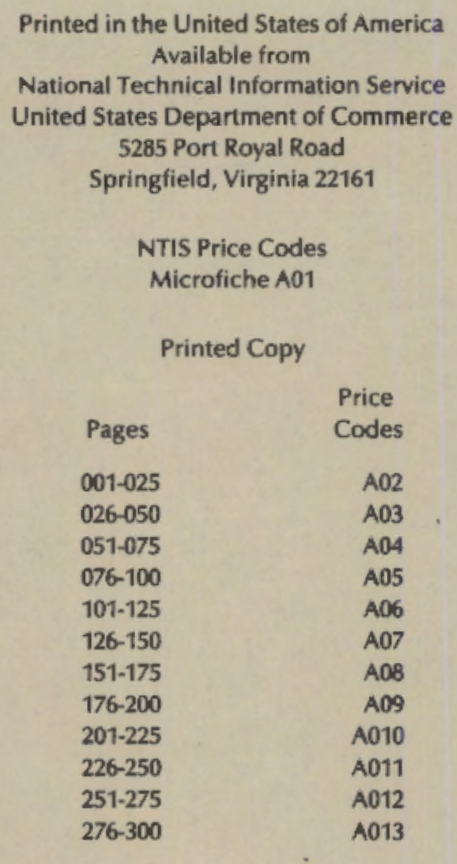


PNL-5733

UC-90

SEPARATION OF GAS MIXTURES

BY SUPPORTED COMPLEXES

D. A. Nelson

M. A. Lilga

December 1986

Prepared for the U.S. Department of Energy Morgantown Energy Technology Center under Contract DE-AC06-76RLO 1830

Pacific Northwest Laboratory Richland, Washington 99352 


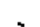




\section{RESEARCH SUMMARY}

This report covers work performed during the period 1 October 1985 through 30 September 1986 by the Pacific Northwest Laboratory (PNL) for the Department of Energy, Morgantown Energy Technology Center.

The goal of this program is to establish the feasibility of coordination complexes as reactive carriers for factlitated transport membrane systems. Emphasis has been placed on systems which can operate using carriers within immobilized liquid membranes requiring stoichiometric or catalytic amounts of transition-metal complexes to accomplish gas separations. The separation of hydrogen from mixtures, such as low-8tu gas, is the specific objective of this research.

In research conducted last year, we found that $\mathrm{Ru}(\mathrm{CO})_{2}\left(\mathrm{PPh}_{3}\right)_{3}$ shows a 2:1 kinetic preference for $\mathrm{H}_{2}$ binding over $\mathrm{CO}$, but that these gases are tightly bound. This year in order to find complexes that bind $\mathrm{H}_{2}$ and $\mathrm{CO}$ reversibly, a series of $R u(C O)_{2} L_{3}$ complexes, where $L$ is phosphine or phosphite, were examined. Early attempts to prepare these complexes by exchange of various ligands (L) into $\mathrm{Ru}(\mathrm{CO})_{2}\left(\mathrm{PPh}_{3}\right)_{3}$ and $\mathrm{RuCl}_{2}\left(\mathrm{PPh}_{3}\right)_{3}$ were unsuccessful, yielding oils or showing no reaction at all. A more general route involves the reaction of excess $L$ with $\left[\mathrm{RuCl}_{2}(\mathrm{CO})_{3}\right]_{2}$ to afford the complexes $\mathrm{RuCl}_{2}(\mathrm{CO})_{2} \mathrm{~L}_{2}$. In analogy to $\mathrm{RuCl}_{2}(\mathrm{CO})_{2}\left(\mathrm{PPh}_{3}\right)_{2}$, these complexes undergo reduction with sodium amalgam in the presence of $L$ to give the desired products. Four of the ten complexes prepared form hydrides when exposed to hydrogen. Each of these four complexes also forms a carbonyl adduct in the presence of carbon monoxide. Only $\mathrm{Ru}(\mathrm{CO})_{2}\left(\mathrm{PPh}_{2} \mathrm{Py}\right)_{3}$ was found to rapidly bind hydrogen then release it within 10 minutes with mild heat. The release is complete and only the starting complex is formed. The other complexes which form hydrides require more than 3 hours to remove hydrogen from the metal center. 
The $\mathrm{Ru}(\mathrm{CO})_{2}\left(\mathrm{PPh}_{2} \mathrm{Py}\right)_{3}$ complex also shows a 2:1 selectivity for $\mathrm{H}_{2}$ binding over Co. The equilibrium constant for $\mathrm{H}_{2}$ binding by $\mathrm{Ru}(\mathrm{CO})_{2}\left(\mathrm{PPh}_{2} \mathrm{Py}\right)_{3}$ is 350 at $25^{\circ} \mathrm{C}$. At $25^{\circ} \mathrm{C}, \mathrm{k}_{\text {obs }}$ for the binding of $\mathrm{CO}, \mathrm{H}_{2}$, and $\mathrm{O}_{2}$ are $6.76 \times 10^{-3} \mathrm{sec}^{-1}$, $7.54 \times 10^{-3} \mathrm{sec}^{-1}$, and $5.92 \times 10^{-3} \mathrm{sec}^{-1}$, respectivety. The similarity of these observed rates may indicate that $\mathrm{PPh}_{2} \mathrm{Py}$ dissociation is limiting. Kinetic measurements at $50^{\circ}$ and $60^{\circ} \mathrm{C}$ are consistent with a two-step mechanism involving initial phosphine dissociation followed by gas addition.

Preparation of cationic dppm and $\mathrm{PPh}_{3}$ ligands containing a quaternary ammonium group was pursued. These ligands are expected to be of use in attaching complexes to an ion exchange membrane for separations of $\mathrm{H}_{2}$ and $\mathrm{CO}$. $\mathrm{A} \mathrm{PPh}_{3}$ derivative was prepared, however, the routes to a dppm derivative were complicated and yielded only small amounts of diphosphine materials that could not be purified.

A system was investigated that catalyzes the dehydrogenation of alcohols and the hydrogenation of ketones. Such a catalyst, if used in a membrane containing an alcohol solvent, might be of use in selective $\mathrm{H}_{2}$ separation from gas mixtures. The dehydrogenation of cyclohexanol and 2-octanol were studied using a $\mathrm{RhCl}_{3} / \mathrm{SnCl}_{2} / \mathrm{LiCl}$ catalyst system. These alcohols are dehydrogenated at rates that are initially rapid, but which gradually slow to a stop. The decrease in rate of $\mathrm{H}_{2}$ evolution is a result of the establishment of an equilibrium between the alcohol and the liberated hydrogen and ketone. At $150^{\circ} \mathrm{C}$, cyclohexanol has the fastest rate of dehydrogenation. Several dehydrogenation/hydrogenation cycles have been carried out using this alcohol over a period of one week without serious catalyst deactivation or side reactions. Initial tests of the catalyst dissolved in cyclohexanol within two membranes were inconclusive. An anion exchange membrane was not suitably wetted by the catalyst solution and Celgard ${ }^{T M}$, which was wetted, could not be kept wet at $150^{\circ} \mathrm{C}$ under flow conditions in the membrane cell. 


\section{CONTENTS}

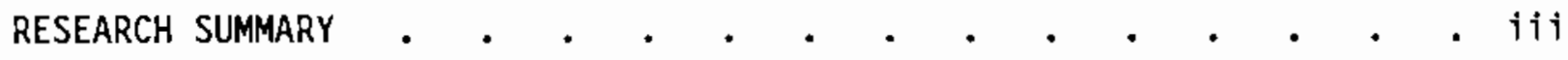

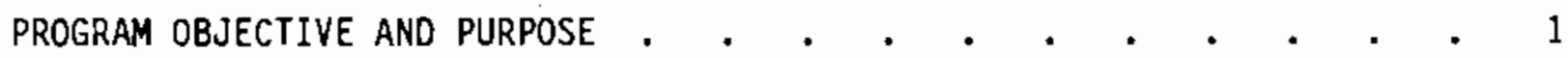

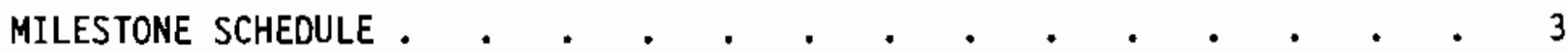

TASK A. ION EXCHANGE ATTACHMENT OF A SYNGAS CARRIER . . . .

TASK B. CATALYTIC FACILITATED TRANSPORT • • • • • • •

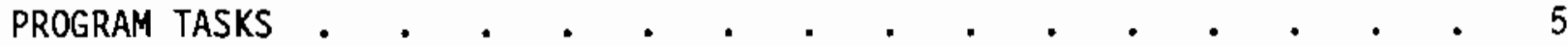

TASK A. ION EXCHANGE ATTACHMENT OF A SYNGAS CARRIER * . . . 5

Subtask A.1. Preparation of Ligand and Complex . . • 5

Subtask A.2. Gas Uptake and Solubilities of the Complexes . 5

Subtask A.3. Attachment of the Complex to a Membrane . . 6

TASK B. CATALYTIC FACILITATED TRANSPORT • • • • • • • $~ 6$

Subtask B.1. Homogeneous Catalysis . . . . . . . . 6

Subtask B.2. Hydrogen Transport Measurement . . . . . 6

DISCUSSION • • •

TASK A. ION EXCHANGE ATTACHMENT OF A SYNGAS CARRIER * ..$\quad$. 9

Subtask A.1. Preparation of Ligand and Complex . . . . 9

Subtask A.2. Gas Uptake and Complex Solubilities . . . 11

Subtask A.3. Attachment of Membrane . . . . . . . 16

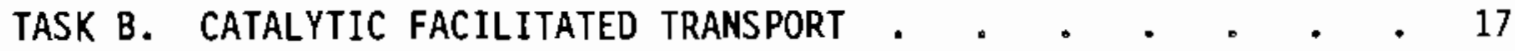

Subtask B.1. Homogeneous Hydrogenation and Dehydrogenation - 17

Subtask B.2. Membrane Attachment and Transport Measurements . 22

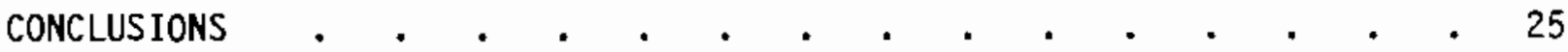

FUTURE DIRECTIONS •

GLOSSARY • • • • • • • • • • • • • • • • . . 29

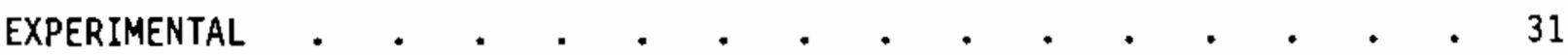

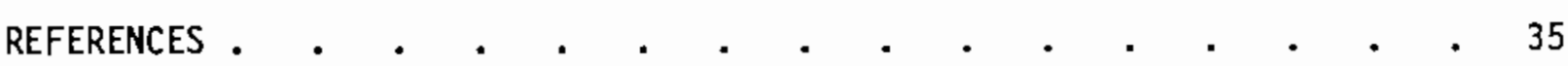

ACKNOWLEDGMENTS . . . . . . . . . . . . . . . . . . 37 


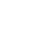




\section{$\underline{\text { FIGURES }}$}

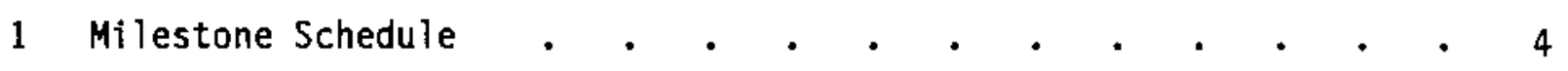

2 Catalytic Facilitated Transport . • • • • . . • • . . 17

3 Cyclohexanol Dehydrogenation at $150^{\circ} \mathrm{C} .+. \quad . \quad . \quad$. . . 20 
TABLES

1 Reaction of $\mathrm{Ru}(\mathrm{CO})_{2}\left(\mathrm{PR}_{3}\right)_{3}$ with Hydrogen at $25^{\circ} \mathrm{C}$ and 1 Atmosphere - 12

2 Values for Forward Observed Rate Constants ( $k_{\text {obs }}$ ) at $25^{\circ}$ and 1 Atmosphere of Gas . . . . . . . . . . . . 14

$3 \quad$ Kinetic Parameters for the Reaction of $\mathrm{H}_{2}\left(200\right.$ torr) and $\mathrm{Ru}(\mathrm{CO})_{2}$ $\left(\mathrm{PPh}_{2} \mathrm{Py}\right)_{3}\left(3.7 \times 10^{-4} \mathrm{M}\right)$ at $50^{\circ}$ and $60^{\circ} \mathrm{C}$. . . . . . 15 
、 


\section{PROGRAM OBJECTIVE AND PURPOSE}

The objective of this program is to establish the feasibility of using coordination complexes as agents in facilitated transport membrane systems. Emphasis has been placed on systems which utilize stoichiometric or catalytic amounts of transition-metal complexes to accomplish gas separations. The separation of hydrogen from mixtures, such as low-BTU gas, is the specific objective of this research. 
,

.

. 


\section{MILESTONE SCHEDULE}

The milestones of each task are shown below and in Figure 1. A more complete discussion of each task follows this outline.

\section{TASK A. ION EXCHANGE ATTACHMENT OF A SYNGAS CARRIER}

A.1 Complete preparation of ligand and complex, 2/86.

A.2 Determine gas uptake and solubilities of complex, $2 / 86$.

A.3 Attach complex to membrane and examine facilitation, 8/86.

TASK B. CATALYTIC FACILITATED TRANSPORT

B.1 Examine homogeneous reactions for catalytic hydrogenation and dehydrogenation, $6 / 86$.

B.2 Measure hydrogen transport of system, $9 / 86$. 


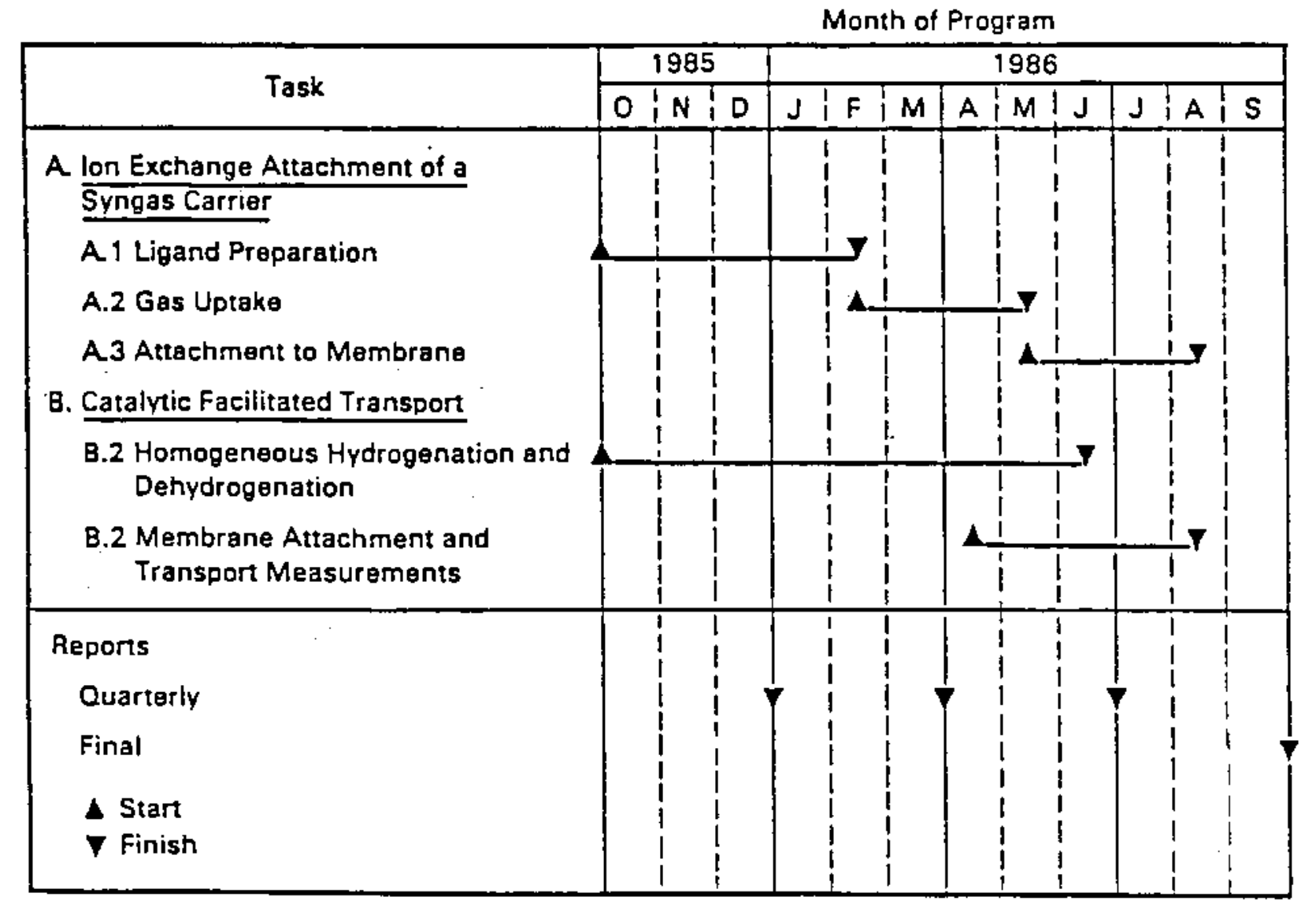

FIGURE 1. Milestone Schedule 


\section{PROGRAM TASKS}

The individual tasks and subtasks are discussed below. Although not identified as a distinct task, there was a considerable effort expended by Pacific Northwest Laboratory to coordinate research activities with the subcontractor and report the research results to DOE-METC. Monthly letter reports, quarterly technical reports, and a final technical report were forwarded to DOE-METC during the normal reporting periods. The 6th Annual Gasification Contractors' meeting was also attended to report the results of this work.

TASK A. ION EXCHANGE ATTACHMENT OF A SYNGAS CARRIER

Subtask A.1. Preparation of Ligand and Complex

The ligand (4-N,N,N-trimethyl ammoniumphenyl) diphenylphosphine tetrafluoroborate will be prepared and incorporated within complexes of the type $\mathrm{Ru}(\mathrm{CO})_{2}\left(\mathrm{PR}_{3}\right)_{3}$. $\mathrm{PR}_{3}$ in these complexes could be phosphites, such as $\mathrm{P}(\mathrm{OMe})_{3}$ and $\mathrm{P}(\mathrm{OPh})_{3}$, or phosphines, such as $\mathrm{PPh}_{3}, \mathrm{P}\left(\mathrm{p}-\mathrm{CH}_{3} \mathrm{C}_{6} \mathrm{H}_{4}\right)_{3}, \mathrm{PBu}_{3}$, and $\mathrm{P}(\mathrm{cyclo}-$ hexyl $)_{3}$. In addition, the ligand $\left[\mathrm{Ph}_{2} \mathrm{PCH}_{2} \mathrm{Ph}\left(\mathrm{C}_{6} \mathrm{H}_{4} \mathrm{NMe}_{3}\right)\right] \mathrm{BF}_{4}$ will be synthesized and used to prepare analogs of the $\operatorname{Pd}_{2}(\mathrm{dppm})_{2} \mathrm{X}_{2}$ complexes. Subtask A.2. Gas Uptake and Solubilities of the Complexes

The derivitized complexes prepared in Subtask A.1 will be examined for their ability to bind both carbon monoxide and hydrogen; i.e., the observed rates will be measured. At the same time the solubilities of the complexes in various solvents suitable for use as an immobilized liquid will be determined. The observed kinetic rates will be measured in the solvent of choice. 
Subtask A.3. Attachment of the Complex to a Membrane

Attachment of one of the above complexes to the ion exchange membrane may require aqueous addition to the solvent. Initial exchange may be investigated using resin beads rather than the membrane. Completion of the attachment will be monitored by elemental analyses and ultraviolet spectrophotometry. Success of the exchange will further be examined by initial measurements of facilitated gas separation, particularly binary and ternary mixtures of carbon monoxide, hydrogen, and nitrogen. An immobilized liquid membrane cell, similar to that developed at the National Bureau of Standards, will be used.

TASK B. CATALYTIC FACILITATED TRANSPORT

Subtask B.1. Homogeneous Catalys is

The catalyst system, $\mathrm{RhCl}_{6}{ }^{3-} / \mathrm{SnCl}_{2} / \mathrm{Cl}^{-}$, necessary for the hydrogenation/ dehydrogenation of ketones/alcohols w111 be examined under homogeneous conditions to determine pressure and temperature requirements. Preliminary rate information will be obtained so that comparisons can be made with the heterogenized systems prepared in Subtask B.2. Catalytic runs will be performed with $\mathrm{NR}_{4}{ }^{+} \mathrm{Cl}^{-}$present in order to mimic the environment present within the membrane.

\section{Subtask B.2. Hydrogen Transport Measurement}

The $\mathrm{RhCl}_{6}{ }^{3-} / \mathrm{SnCl}_{2} / \mathrm{Cl}^{-}$catalyst system should be easily immobilized within an anion exchange membrane. Addition of excess chloride may not be necessary (depending upon $\mathrm{RhCl}_{6}{ }^{3-}$ loading) since chloride is typically the initial counterion present in these membranes. The flux of $\mathrm{H}_{2}$ across the membrane will be measured using gc analysis of the sweep and feed gases with and 
without the carrier present. A mixed gas feed consisting of $\mathrm{N}_{2}, \mathrm{H}_{2}, \mathrm{CO}_{2}, \mathrm{CO}$, and $\mathrm{CH}_{4}$ will be studied to determine selectivity for $\mathrm{H}_{2}$. 


\section{DISCUSSION}

TASK A. ION EXCHANGE ATTACHMENT OF A SYNGAS CARRIER

Subtask A.1. Preparation of Ligand and Complex

$\mathrm{Ru}(\mathrm{CO})_{2}\left(\mathrm{PPh}_{3}\right)_{3}$, studied in our previous work [1], was shown to bind $\mathrm{H}_{2}$ and $\mathrm{C} 0$. A 2:1 kinetic preference for $\mathrm{H}_{2}$ binding was demonstrated. When the complex was used in the dual column reactor with a mixed gas feed, however, it was found that the co complex was thermodynamically preferred. Under the conditions of those experiments co could not be stripped because of its tight binding to the Ru center. Since altering the steric and electronic properties of ligands is known to have large effects on complex reactivity (i.e., binding of small molecules such as $\mathrm{CO}$ and $\mathrm{H}_{2}$ ), a series of phosphine and phosphite substituted complexes, $\mathrm{Ru}\left(\mathrm{CO}_{2}\left(\mathrm{PR}_{3}\right)_{3}\right.$, were desired. Once in hand, these complexes would be subjected to $\mathrm{CO}$ and $\mathrm{H}_{2}$ to determine whether reversible binding occurs and whether there is selectivity for one component.

Three synthetic approaches to these complexes have been attempted. Direct ligand exchange was unsuccessful starting with $\mathrm{Ru}(\mathrm{CO})_{2}\left(\mathrm{PPh}_{3}\right)_{3}$ and excess $\mathrm{P}(\mathrm{OMe})_{3}, \mathrm{P}(\mathrm{p}-\mathrm{tol})_{3}, \mathrm{PCy}_{3}$, and $\mathrm{P}\left(\mathrm{p}-\mathrm{ClC}_{6} \mathrm{H}_{4}\right)_{3}$, where $\mathrm{p}$-tol is $\mathrm{p}-\mathrm{CH}_{3} \mathrm{C}_{6} \mathrm{H}_{4}$ and $\mathrm{Cy}$ is cyclohexyl. Impure products, usually oils, were obtained. The reaction mixture of $\mathrm{Ru}(\mathrm{CO})_{2}\left(\mathrm{PPh}_{3}\right)_{3}$ and $\mathrm{PCy}_{3}$ showed no reaction with $\mathrm{H}_{2}$ after two days in THF. Phosphine exchange was also attempted with $\mathrm{RuCl}_{2}\left(\mathrm{PPh}_{3}\right)_{3}$. $\mathrm{PCy}_{3}$ and $\mathrm{P}(\mathrm{OMe})_{3}$ did not exchange; however, $\mathrm{P}(\mathrm{p}-\mathrm{tol})_{3}$ and $\mathrm{P}(\mathrm{OPh})_{3}$ apparently did.

A more general and successful approach to these materials is the reaction of phosphine with $\left[\mathrm{RuCl}_{2}(\mathrm{CO})_{3}\right]_{2}$. With $\mathrm{PPh}_{3}$ this reaction is known to give $\mathrm{RuCl}_{2}(\mathrm{CO})_{2}\left(\mathrm{PPh}_{3}\right)_{2}$ which can be reduced with sodium amalgam in the presence of $\mathrm{PPh}_{3}$ to give $\mathrm{Ru}(\mathrm{CO})_{2}\left(\mathrm{PPh}_{3}\right)_{3}$. The reaction of $\left[\mathrm{RuCl}_{2}(\mathrm{CO})_{3}\right]_{2}$ or $\mathrm{RuCl}_{2}(\mathrm{CO})_{2}$ (thf) 2 (thf $=$ tetrahydrofuran) with $\mathrm{PR}_{3}$ affords the analogous 
$\mathrm{RuCl}_{2}(\mathrm{CO})_{2}\left(\mathrm{PR}_{3}\right)_{2}$ complexes, where $\mathrm{PR}_{3}$ is $\mathrm{P}(\mathrm{p}-\mathrm{tol})_{3}, \mathrm{P}\left(\mathrm{p}-\mathrm{C}_{6} \mathrm{H}_{4} \mathrm{OMe}\right)_{3}, \mathrm{PCy} y_{3}$, $\mathrm{PPhCy}_{2}, \mathrm{PPh}_{2}(\mathrm{a} l \mathrm{l} \mathrm{yl}), \mathrm{PPh}(\mathrm{a} l \mathrm{lyl})_{2}, \mathrm{PPh}_{2} \mathrm{Py}\left(\mathrm{py}=\right.$ pyridyl), $\mathrm{PPh}(\mathrm{OMe})_{2}, \mathrm{P}(\mathrm{OMe})_{3}$, and $\mathrm{P}(\mathrm{OPh})_{3} . \mathrm{P}(\mathrm{p}-\text { tol })_{3}$ gave the same material as in the exchange reactions with $\mathrm{RuCl}_{2}\left(\mathrm{PPh}_{3}\right)_{3}$ followed by a $\mathrm{CO}$ purge and is probably $\mathrm{RuCl}_{2}(\mathrm{CO})_{2}(\mathrm{P}(\mathrm{P}-$ tol $\left.)_{3}\right)_{2}$. The bulkier $\mathrm{PCy}_{3}$ and $\mathrm{PPhCy}_{2}$ gave mixtures of two compounds which may be cis and trans isomers.

Sodium amalgam reduction in the presence of added ligand afforded $\mathrm{Ru}(\mathrm{CO})_{2}\left(\mathrm{PR}_{3}\right)_{3}$. Each of these complexes was treated with $\mathrm{H}_{2}$ gas while in solution (usually thf). The results of the hydrogen reactions are presented in Table 1, Section A.2.

The complex $\mathrm{RuH}_{2}(\mathrm{CO})_{2}\left(\mathrm{PPh}_{2} \mathrm{py}\right)_{2}$ (py = pyridyl) has been synthesized, isolated, and characterized. This complex is prepared by precipitation from a hydrogen-saturated thf solution of $\mathrm{Ru}(\mathrm{CO})_{2}\left(\mathrm{PPh}_{2} \mathrm{py}\right)_{3}$ with hydrogen-saturated hexane. The reaction of $\mathrm{H}_{2}$ with $\mathrm{Ru}(\mathrm{CO})_{2}\left(\mathrm{PPh}_{2} \mathrm{py}\right)_{3}$ to form the dihydride is reversible as discussed in Subtask A.2 and it is important to the kinetic determination that the dihydride be isolated and well-characterized.

In a related study, the complex RuMo $(\mathrm{CO})_{5}(\mathrm{dppm})_{2}$ was prepared and examined for reversible $\mathrm{H}_{2}$ and $\mathrm{CO}$ binding. This complex was previously reported to react reversibly with $\mathrm{CO}$ but reversibility with $\mathrm{H}_{2}$ and specificity were not reported [2]. In our study, it was found that both react reversibly. This complex is prepared by the reaction of $\mathrm{RuH}_{2}(\mathrm{dppm})_{2}$ with Mo(CO) 6 to afford RuMo $(\mathrm{CO})_{6}(\mathrm{dppm})_{2}$ from which $\mathrm{CO}$ is liberated under vacuum. $\mathrm{RuH}_{2}(\mathrm{dppm})_{2}$ is prepared from $\mathrm{Ru}(\mathrm{COD})(\mathrm{COT})$ (COD is cyclooctadine and COT is cyclooctatetraene), dppm, and $\mathrm{H}_{2}$ in toluene solution.

The preparation of two cationic phosphine ligands was attempted. The target ligands are derivatized $\mathrm{PPh}_{3}$ and dppm compounds containing trimethy ammonium substitution in the para position of a phenyl group. These ligands 
could be incorporated into the ruthenfum complexes discussed above or into the $\operatorname{Pd}_{2}(\mathrm{dppm})_{2} \mathrm{X}_{2}$ complexes which we have previously shown to be agents for $\mathrm{H}_{2}$ separation.

An intermediate expected to be of importance in the preparation of both ligands is $\mathrm{PPh}\left(\mathrm{C}_{6} \mathrm{H}_{4} \mathrm{MMe}_{2}\right) \mathrm{Cl}$. This phosphine is an air sensitive yellow solid prepared by reaction of $\mathrm{PPhCl}_{2}$ and $\mathrm{BrMgC}_{6} \mathrm{H}_{4} \mathrm{NMe}_{2}$. The ${ }^{1} \mathrm{H}$ and ${ }^{31} \mathrm{P}-\mathrm{NMR}$ spectra are consistent with the given formula. When this material is reacted with one equivalent of $\mathrm{PhMgBr}$ the expected diphenylaminophenyl product [3] is not obtained. Instead, a 24\% yield of $\mathrm{PPh}\left(\mathrm{C}_{6} \mathrm{H}_{4} \mathrm{NMe}_{2}\right)_{2}$ is isolated. A redistri, bution reaction apparently occurs and the desired $\mathrm{PPh}_{2}\left(\mathrm{C}_{6} \mathrm{H}_{4} \mathrm{NMe}_{2}\right)$ could not be obtained.

PPh $\left(\mathrm{C}_{6} \mathrm{H}_{4} \mathrm{NMe}_{2}\right)_{2}$ is also isolated in the attempted preparation of a derivatized dppm ligand when $\mathrm{PPh}\left(\mathrm{C}_{6} \mathrm{H}_{4} \mathrm{NMe}_{2}\right) \mathrm{Cl}$ is reacted with $\mathrm{PPh}_{2} \mathrm{CH}_{2}{ }^{-} \mathrm{Li}^{+}$- TMEDA (TMEDA is tetramethylethylenediamine) [4]. The expected product $\mathrm{Ph}_{2} \mathrm{PCH}_{2} \mathrm{PPh}-$ $\left(\mathrm{C}_{6} \mathrm{H}_{4} \mathrm{NMe}_{2}\right)$ was not detected. An alternative strategy was devised in which $\mathrm{Ph}_{2} \mathrm{P}(\mathrm{O}) \mathrm{CH}_{2} \mathrm{PPhCl}$ would be prepared from $\mathrm{OPPh}_{2} \mathrm{CH}_{2} \mathrm{Li}^{+}$and $\mathrm{PPhCl}_{2}$, two easily prepared starting materials. While a white precipitate formed rapidly when the lithium reagent was added dropwise to the phosphine chloride, the product was found to be a mixture of compounds. Diphosphine components were present but could not be isolated.

\section{Subtask A.2. Gas Uptake and Complex Solubilities}

The reactivity of each of the $\mathrm{Ru}(\mathrm{CO})_{2}\left(\mathrm{PR}_{3}\right)_{3}$ complexes with $\mathrm{H}_{2}$ was tested in thf solution. The results of the tests are summarized in Table 1. Ligand substitution results in complexes with reactivity ranging from no $\mathrm{H}_{2}$ uptake to reversible and irreversible binding. Our previous work indicated that $\mathrm{Ru}(\mathrm{H})_{2}(\mathrm{CO})_{2}\left(\mathrm{PPh}_{3}\right)_{2}$ requires over 7 hours at $65^{\circ} \mathrm{C}$ (under nitrogen) to release the hydrogen. Further, the hydrogen release is not clean; i.e., at least two major products and two minor products are formed. Similar results were 
obtained with complexes containing the p-methoxyphenyl and p-tolyl phosphine ligands. The hydrogen removal is incomplete after 3 hours, but several products are also evident. After 4 hours at $65^{\circ} \mathrm{C}, \mathrm{Ru}(\mathrm{H})_{2}(\mathrm{CO})_{2}\left(\mathrm{PCy}_{3}\right)_{2}$ is almost completely intact. Some trace products were detected. of considerable interest is $\mathrm{Ru}(\mathrm{H})_{2}(\mathrm{CO})_{2}\left(\mathrm{PPh}_{2} \mathrm{Py}\right)_{2}$. This complex totally releases hydrogen within 10 minutes and cleanly reforms the starting complex. Furthermore, $\mathrm{Ru}(\mathrm{CO})_{2}\left(\mathrm{PPh}_{2} \mathrm{Py}\right)_{3}$ shows a preference toward $\mathrm{H}_{2}$ binding over $\mathrm{CO}$. A solution of the complex reacts with a 50:50 mixture of $\mathrm{H}_{2}$ and $\mathrm{CO}$ to afford a 70:30 hydride to carbonyl adduct product ratio based on ${ }^{1} H$ NMR integration. It is not known at this time whether this is a kinetic or thermodynamic product mixture.

TABLE 1. Reaction of $\mathrm{Ru}(\mathrm{CO})_{2}\left(\mathrm{PR}_{3}\right)_{3}$ with Hydrogen at $25^{\circ} \mathrm{C}$ and 1 Atmosphere ${ }^{\text {(a) }}$

\begin{tabular}{ll}
\multicolumn{1}{c}{$\mathrm{PR}_{3}$ or $\mathrm{P}(\mathrm{OR})_{3}$} & Hydride \\
\cline { 1 - 2 } diphenylpyridylphosphine & yes \\
tri(p-tolyl)phosphine & yes \\
tri(p-methoxyphenyl)phosphine & yes \\
tricyclohexylphosphine & yes \\
allyldiphenylphosphine & no \\
diallylphenylphosphine & no \\
dimethoxyphenylphosphine & no \\
diphenylmethoxyphosphine & no \\
trimethoxyphosphite & no \\
triphenoxyphosphite & no
\end{tabular}

(a) The complexes were considered inert to hydrogen if no hydride formed within 24 hours.

The kinetics and thermodynamics of $\mathrm{H}_{2}$ binding to $\mathrm{Ru}(\mathrm{CO})_{2}\left(\mathrm{PPh}_{2} \mathrm{Py}\right)_{3}$ were determined. The ruthenium (0) complex was examined for $\mathrm{H}_{2}$ uptake in a dimethylacetamide (dma) solution at $25^{\circ} \mathrm{C}$. The equilibrium constant for $\mathrm{H}_{2}$ 
binding, originally determined by us to be 700 , was established by uv/vis spectroscopy at $375 \mathrm{~nm}$ and $450 \mathrm{~nm}$ (an average of both). However, this value was in error due to impurities in the dma solvent. These impurities reacted with the Ru(0) complex resulting in competing absorptivities. The problem was resolved by performing a final distillation of the dma from some of the $\mathrm{Ru}(0)$ complex prior to its use in the equilibrium experiments. Reproducible results were obtained with this solvent, and an equilibrium constant for $\mathrm{H}_{2}$ binding of 350 at $25^{\circ} \mathrm{C}$ was confirmed. This small value indicates that release of hydrogen is favored al though the hydrogen uptake was quite fast. The original complex which was examined earlier, $\mathrm{Ru}(\mathrm{CO})_{2}\left(\mathrm{PPh}_{3}\right)_{3}$, had an equilibrium constant of $10^{4}-10^{5}$. This large value favored hydride formation but not hydrogen release.

The kinetics of hydrogen binding by $\mathrm{Ru}(\mathrm{CO})_{2}\left(\mathrm{PPh}_{2} \mathrm{py}\right)_{3}$ were too slow at $25^{\circ} \mathrm{C}$ for the use of stopped-flow equipment, requiring the use of standard $u v / v i s$ methods for work at this temperature. The $t_{1 / 2}$ for $H_{2}$ binding (time required for $50 \%$ of the complex to react) was $150 \mathrm{sec}$ at $25^{\circ} \mathrm{C}$. Stopped-flow was used at temperatures above $40^{\circ} \mathrm{C}$ in order to obtain more accurate rate and thermodynamic data. The solvent in these studies was dma.

Initially, $\mathrm{H}_{2}, \mathrm{CO}$, and $\mathrm{O}_{2}$ were added individually to dma solutions of $\mathrm{Ru}(\mathrm{CO})_{2}\left(\mathrm{PPh}_{2} \mathrm{Py}\right)_{3}$ at $25^{\circ} \mathrm{C}$. The results are shown in Table 2. The similarity 
TABLE 2. Values for Forward observed Rate Constants ( $k_{\text {obs }}$ ) at $25^{\circ} \mathrm{C}$ and 1 Atmosphere of Gas
CO $\left(\mathrm{s}^{-1}\right)$
$\mathrm{H}_{2}\left(\mathrm{~s}^{-1}\right)$
$\underline{0}_{2}\left(\mathrm{~s}^{-1}\right)$
$6.76 \times 10^{-3}$
$7.54 \times 10^{-3}$
$5.9210^{-3}$

of $\mathrm{k}_{\text {obs }}$ values suggests that diffusion of gas into the dma could be limiting or that dissociation of a $\mathrm{PPh}_{2} \mathrm{Py}$ ligand is required to provide a site for gas binding. A two-step mechanism, an initial phosphine dissociation followed by $\mathrm{H}_{2}$ addition, was found to operate in gas binding to $\mathrm{Ru}(\mathrm{CO})_{2}\left(\mathrm{PPh}_{3}\right)_{3}$ and probably also operates for the very similar $\mathrm{PPh}_{2} \mathrm{py}$-containing complex. This mechanism is shown below.

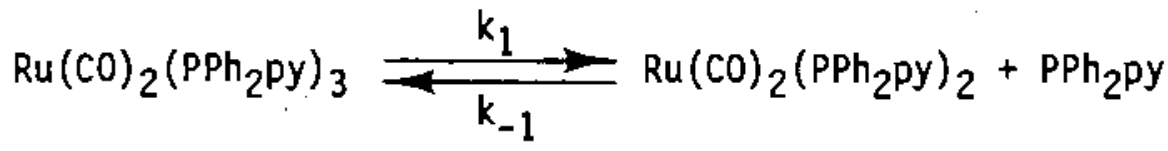

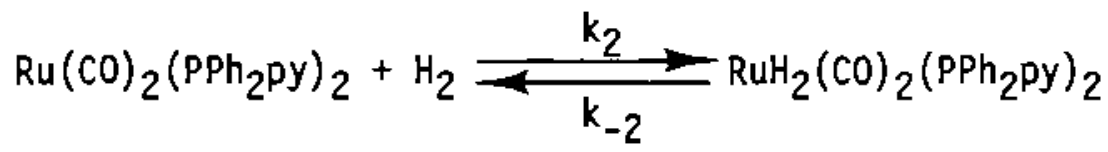

The overall observed rate for this process is expressed as:

$$
\text { rate }=\frac{\mathrm{k}_{1} \mathrm{k}_{2}\left[\mathrm{Ru}(\mathrm{CO})_{2}\left(\mathrm{PPh}_{2} \mathrm{Py}_{3}\right]\left[\mathrm{H}_{2}\right]\right.}{\mathrm{k}_{-1}\left[\mathrm{PPh}_{2} \mathrm{Py}\right]+\mathrm{k}_{2}\left[\mathrm{H}_{2}\right]}
$$

First-order kinetics are achieved by holding the complex and $\mathrm{H}_{2}$ concentrations constant while varying the phosphine concentration. Under these conditions the following relationships describes the observed rate:

$$
k_{\text {obs }}=\frac{k_{1} k_{2}\left[\mathrm{H}_{2}\right]}{k_{-1}\left[\mathrm{PPh}_{2} \mathrm{py}\right]+k_{2}\left[\mathrm{H}_{2}\right]}
$$




$$
k_{\text {obs }}{ }^{-1}=\frac{k_{-1}\left[\mathrm{PPh}_{2} \mathrm{py}\right]}{k_{1} \mathrm{k}_{2}\left[\mathrm{H}_{2}\right]}+\frac{1}{k_{1}}
$$

By plotting $\left[\mathrm{PPh}_{2} \mathrm{Py}\right]$ vs. $\mathrm{k}_{\mathrm{obs}}{ }^{-1}, \mathrm{k}_{1}$ is determined from the intercept and the ratio $k_{-1} / k_{2}$ is obtained from the slope. Also, $k_{1}$ equals $k_{\text {obs }}$ at 1 atm $\mathrm{H}_{2}$ pressure when the $\left[\mathrm{PPh}_{2} \mathrm{Py}\right] /[\mathrm{Ru}]$ ratio is less than 20 since the $\mathrm{k}_{-1}\left[\mathrm{PPh}_{2} \mathrm{Py}\right]$ term is much smaller than the $k_{2}\left[H_{2}\right]$ term in equation 3 . The dependence of $k_{\text {obs }}$ on phosphine concentration was most apparent at a hydrogen pressure of 200 torr. The results of data taken at this pressure at $50^{\circ}$ and $60^{\circ} \mathrm{C}$ with a $\mathrm{Ru}(\mathrm{CO})_{2}\left(\mathrm{PPh}_{2} \mathrm{Py}\right)_{3}$ concentration of $3.7 \times 10^{-4} \underline{\mathrm{M}}$ are summarized in Table 3 . values of $k_{1}$ at $50^{\circ}$ and $60^{\circ} \mathrm{C}$ obtained graphically from the phosphine variation method agree well with the values obtained when no phosphine is added. This is not the case for data taken at $25^{\circ} \mathrm{C}$ which indicate a $k_{1}$ of $0.0014 \mathrm{sec}^{-1}$ from the phosphine variation method and $0.0059 \mathrm{sec}^{-1}$ from runs where no phosphine was added. The discrepancy may be due to a limitation caused by $\mathrm{H}_{2}$ diffusion into the solution. A comparison of these kinetics to the kinetics of $\mathrm{H}_{2}$ binding by the $\mathrm{PPh}_{3}$-containing complex (conducted at $25^{\circ} \mathrm{C}$ ) unfortunately cannot be made until the $25^{\circ} \mathrm{C}$ data reported here are more fully understood.

TABLE 3. Kinetic parameters for the Reaction of $\mathrm{H}_{2}$ (200 torr) and $\mathrm{Ru}(\mathrm{CO})_{2}\left(\mathrm{PPh}_{2} \mathrm{Py}\right)_{3}\left(3.7 \times 10^{-4} \underline{\mathrm{M}}\right)$ at $50^{\circ}$ and $60^{\circ} \mathrm{C}$

$\begin{array}{lcc}\text { IOC }^{\circ} & \underline{k}_{1} & \underline{k_{-1} / k_{2}} \\ 50 & 0.0747 & 2.59 \times 10^{-4}\left[\mathrm{H}_{2}\right] \\ 60 & 0.2984 & 2.34 \times 10^{-3}\left[\mathrm{H}_{2}\right]\end{array}$

$\mathrm{H}_{2}$ binding by $\mathrm{Ru}(\mathrm{CO})_{2}\left(\mathrm{PPh}_{2} \mathrm{Py}\right)_{3}$ was found to be first order in the complex and zero order in $\mathrm{H}_{2}$. Measurements of $k_{\text {obs }}$ were also made at various temperatures with constant hydrogen and $R u$ complex concentrations with no 
added phosphine. The Arrhenius plot of ln $k_{\text {obs }}\left(k_{\text {obs }}=k_{1}\right.$ under these conditions) vs. $1 / \mathrm{T}$ is linear and yields an activation energy of $87.6 \mathrm{~kJ} / \mathrm{mole} \mathrm{o}^{\circ} \mathrm{K}$. The rate of $\mathrm{H}_{2}$ release from $\mathrm{RuH}_{2}(\mathrm{CO})_{2}\left(\mathrm{PPh}_{2} \mathrm{Py}\right)_{2}, \mathrm{k}_{-2}$, was determined at $60^{\circ} \mathrm{C}$. The ruthenium hydride complex and 100 equivalents of added phosphine were heated in dma under vacuum. At two different complex concentrations the value of $k_{-2}$ was $2.67 \times 10^{-4} \mathrm{sec}^{-1}$ indicating either the expected first order dependence on complex or that the off-rate is controlled by diffusion of $\mathrm{H}_{2}$ from the solvent.

$$
\mathrm{RuMo}(\mathrm{CO})_{6}(\mathrm{dppm})_{2} \underset{\text { heat }}{\stackrel{\mathrm{C} 0}{\rightleftharpoons}} \mathrm{RuMo}(\mathrm{CO})_{5}(\mathrm{dppm})_{2} \underset{\text { heat }}{\stackrel{\mathrm{H}_{2}}{\rightleftharpoons}} \mathrm{RuMoH}_{2}(\mathrm{CO})_{5}(\mathrm{dppm})_{2}
$$

The binding of both $\mathrm{H}_{2}$ and $\mathrm{CO}$ to RuMo $(\mathrm{CO})_{5}$ (dppm) 2 was found to be reversible according to eq. 6 . Exposure of the complex to a $1: 1$ mixture of $\mathrm{H}_{2}$ and $\mathrm{CO}$ forms the hydride and carbonyl adducts in 2:3 ratio respectively. Binding of hydrogen and carbon monoxide are very fast. The carbonyl adduct, RuMo $(\mathrm{CO})_{6}(\mathrm{dppm})_{2}$, reforms the pentacarbonyl complex within a 20 -minute period at $80^{\circ} \mathrm{C}$. Also, the carbonyl adduct is completely converted to the hydride after a 20-minute exposure to hydrogen gas. Approximately $30 \%$ of the hydrogen is removed from RuMo $(\mathrm{H})_{2}(\mathrm{CO})_{5}(\mathrm{dppm})_{5}$ at elevated temperature within 20 minutes.

Subtask A.3. Attachment of the Complex to a Membrane

A Ru(CO) ${ }_{2}\left(\mathrm{PR}_{3}\right)_{3}$ complex derivatized with a cationic phosphine was to have been attached to a membrane. We were unable to prepare the cationic phosphine, however, owing to a more complicated phosphine reaction chemistry than anticipated. 
TASK B. CATALYTIC FACILITATED TRANSPORT

Subtask B.1. Homogeneous Hydrogenation and Dehydrogenation

A strategy that we consider promising for $\mathrm{H}_{2}$ separation, and to our knowledge has not been investigated, is the use of catalysts that will reversibly incorporate hydrogen into a substrate $(S)$ that is also the reaction solvent; i.e., catalyze hydrogenation and dehydrogenation reactions (Equation 7). Such a catalyst/substrate system in an immobilized liquid membrane (ILM)

$$
\mathrm{S}+\mathrm{H}_{2} \stackrel{\text { catalyst }}{\longrightarrow} \mathrm{S}(\mathrm{H})_{2}
$$

will give facilitated transport of hydrogen where the carrier is now the substrate rather than the transition metal. The concept is illustrated in Figure 2.

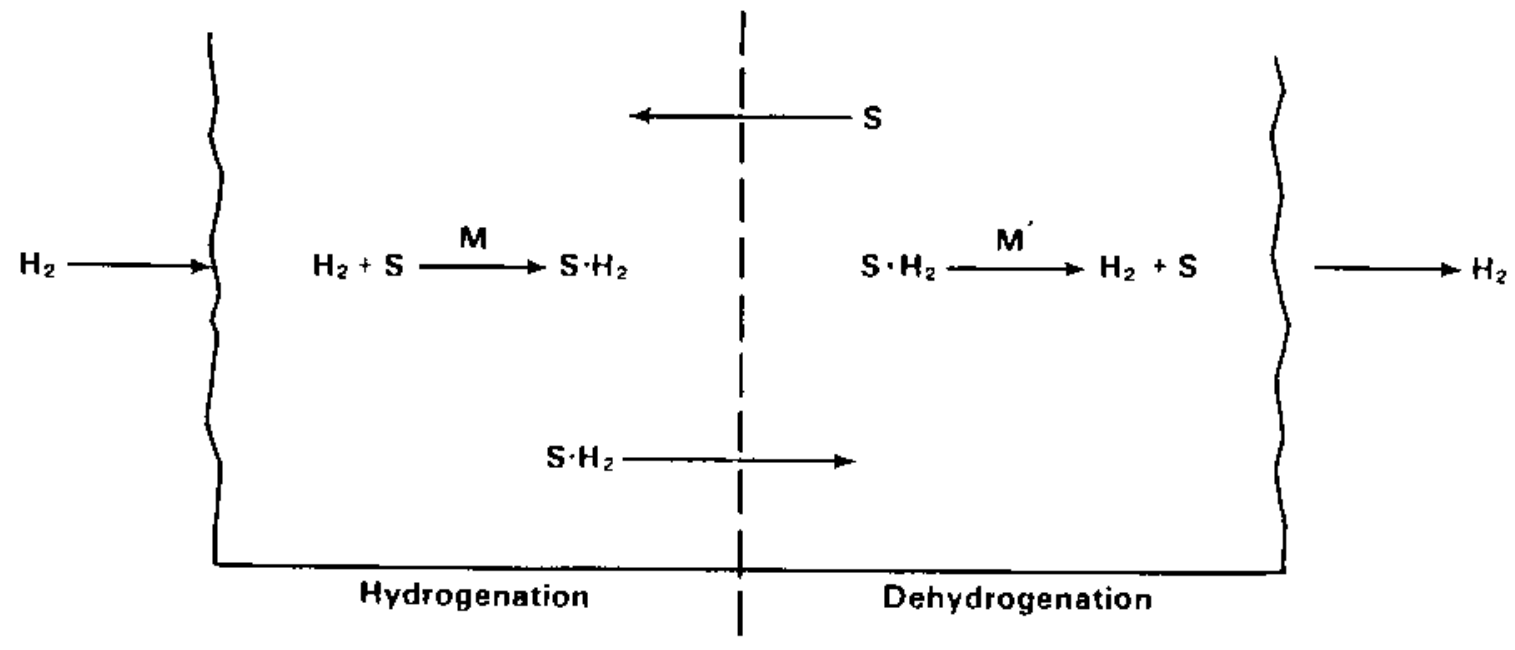

FIGURE 2. Catalytic Facilitated Transport 
The ultimate driving force for $\mathrm{H}_{2}$ permeation in this catalytic system is the differential partial pressure of $\mathrm{H}_{2}$ on either side of the membrane. Hydrogen entering the membrane is used to hydrogenate an unsaturated substrate. The hydrogenated substrate diffuses across the membrane and is dehydrogenated forming hydrogen, which exits the low pressure side. This allows the substrate to diffuse back across the membrane. The effective hydrogen concentration within the membrane (concentration of dissolved $\mathrm{H}_{2}+$ concentration of hydrogenated substrate) is not limited by the normal solubility of $\mathrm{H}_{2}$ in the solvent resulting in high $\mathrm{H}_{2}$ selectivity. Hydrogen permeability is, in part, a function of the kinetics of the overall reaction.

We expect that the transition metal concentration in a catalytic facilitated transport system will be approximately two orders of magnitude less than that in a transition metal carrier system. Thus, the utilization of the transition metal complex is much more efficient since the metal merely acts as a shuttle between dissolved $\mathrm{H}_{2}$ and the actual substrate carrier. The use of catalytic amounts of complex considerably lowers capital outlay without sacrificing selectivity or permeability.

The simplest approach toward utilization of a hydrogenation/dehydrogenation scheme is one in which a single catalyst, capable of catalysis of both the forward and reverse reactions of Equation 7 , is contained in an ILM. Such a catalyst system is hexchiororhodate anion, $\mathrm{RhCl}_{6}{ }^{3-}$, in the presence of $\mathrm{SnCl}_{2}$ and $\mathrm{HCl}$ [5-8]. This system catalyzes the dehydrogenation of isopropanol to form $\mathrm{H}_{2}$ and acetone at $82^{\circ} \mathrm{C}$. Acetone build-up inhibits the reaction owing to reversal of Equation 8. Other alcohols such as ethanol, 1-butanol, 2-butanol, and 2-methy1-1-propanol also have been dehydrogenated. It is 


$$
\mathrm{CH}_{3} \mathrm{CH}(\mathrm{OH}) \mathrm{CH}_{3} \stackrel{\mathrm{RhCl}_{6}^{3-} / \mathrm{SnCl}_{2} / \mathrm{HCl}}{\longrightarrow} \mathrm{CH}_{3} \mathrm{C}(\mathrm{O}) \mathrm{CH}_{3}+\mathrm{H}_{2}
$$

expected that this catalyst could easily be incorporated within an anion exchange resin and used for catalytic facilitated transport of hydrogen.

The dehydrogenation of alcohols appears to be general. Less volatile alcohol/ketone systems, which are desirable in a membrane application in order to minimize evaporative losses, were used in this study. As a result, higher temperatures and faster rates were obtainable. Hydrogenation and dehydrogenation processes were studied separately using a reaction flask connected to a simple gas buret. Dehydrogenation was studied initially. All of the alcohols liberated hydrogen at the maximum rates shown in Table 4. Maximum rates were typically measured within the first hour of commencement of $\mathrm{H}_{2}$ evolution. $\mathrm{H}_{2}$ evolution did not start until the solution, which was originally red, turned black.

2,5-hexanediol was inftially studied but was abandoned when it was discovered that a resultant mono- or di-ketone product irreversibly cyclized to form a furan ring. 2-octanol dehydrogenates cleanly to 2-octanone and $\mathrm{H}_{2}$. The rate of hydrogen evolution gradually slows to a stop after $120 \mathrm{hr}$. A N 2 flush of the atmosphere over the reaction solution to remove liberated $\mathrm{H}_{2}$ results in the continuation of $\mathrm{H}_{2}$ generation at a slow rate, indicating a shift in equilibrium.

Cyclohexanol shows similar behavior (Figure 3 ) but is dehydrogenated much more rapidly than any of the other alcohols studied. If the atmosphere is swept with $\mathrm{N}_{2}, \mathrm{H}_{2}$ evolution continues. The cyclohexanone concentration in 


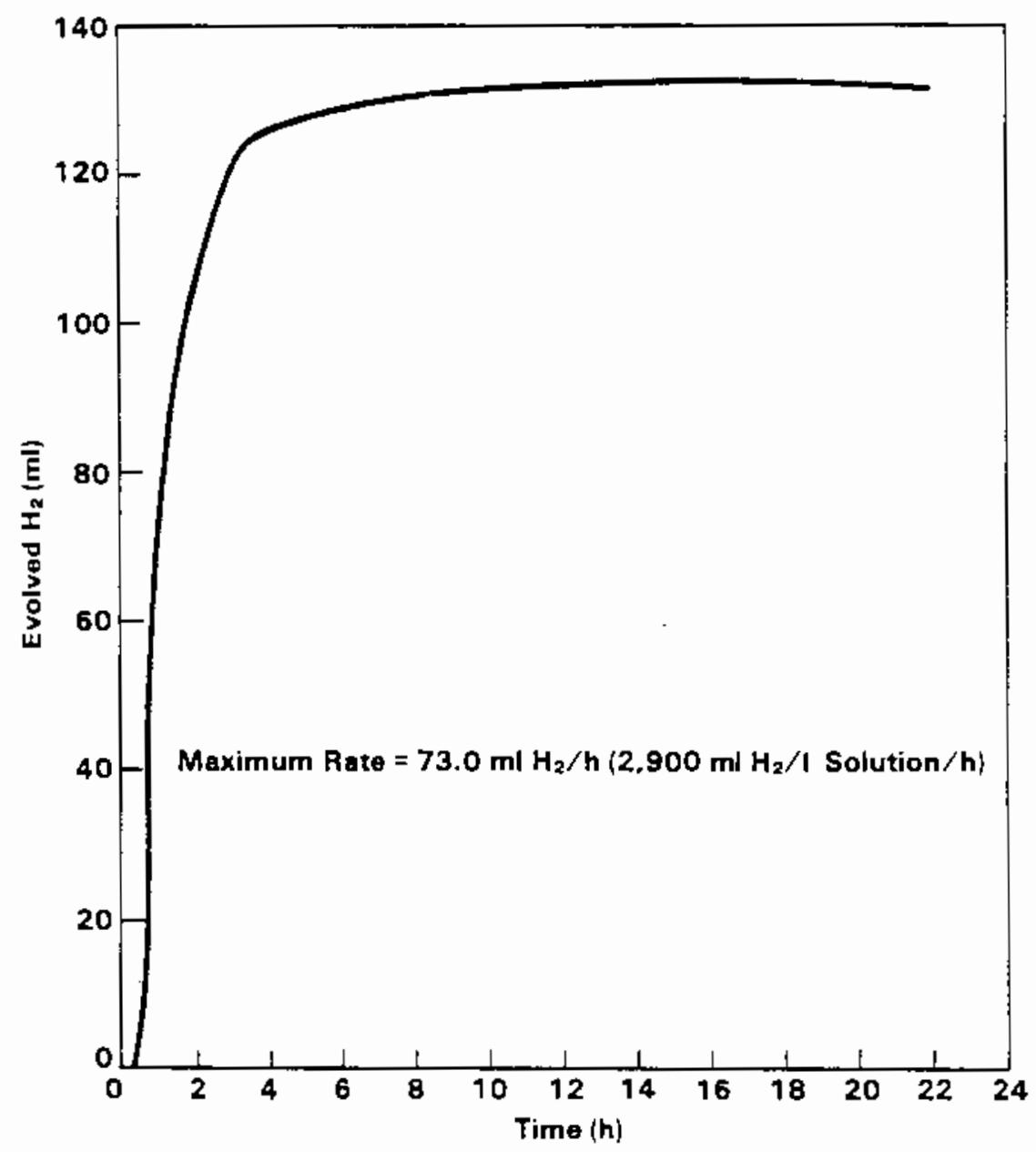

FIGURE 3. Cyclohexanol Dehydrogenation at $150^{\circ} \mathrm{C}$

TABLE 4. Maximum Rates of Hydrogen Evolution in Alcohol Dehydrogenation by $\mathrm{RhCl}_{3} / \mathrm{SnCl}_{2} / \mathrm{LiCl}$ (a)

\begin{tabular}{lcc}
\multicolumn{1}{c}{ Alcohol } & $\mathrm{mT}\left(\mathrm{H}_{2}\right) / l$ (solution) $/ \mathrm{h}$ & $\frac{\mathrm{T}\left({ }^{\circ} \mathrm{C}\right)}{110}$ \\
cyclohexanol & 28 & 150 \\
cyclohexanol & 2,900 & 170 \\
cyclohexanol & 13,800 & 150 \\
2-octanol & 570 & 150 \\
2,5-hexanediol & 320 & 83 \\
isopropanol & 0.5 &
\end{tabular}

(a) $\left[\mathrm{RhCl}_{3}\right]=0.008 \underline{\mathrm{M}}_{1}\left[\mathrm{SnCl}_{2}\right]=0.07 \underline{\mathrm{M}}_{1}[\mathrm{LiCl}]=0.17 \underline{\mathrm{M}}$ 
the equilibrium mixture is very low, i.e. the equilibrium lies well toward cyclohexanol (eq. 9). If the system is purged with $\mathrm{H}_{2}$, an uptake of gas is

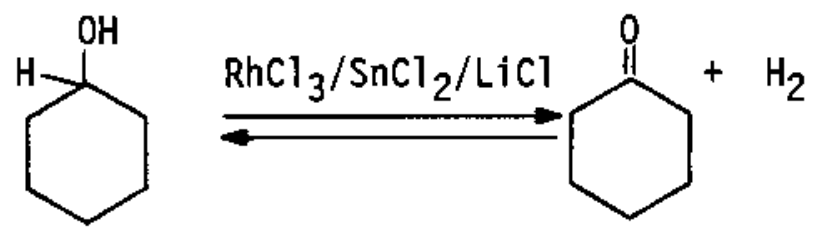

noted, indicating that hydrogenation is taking place. The cyclohexanol/ cyclohexanone system was cycled through three dehydrogenation/hydrogenation procedures over the course of one week at $150^{\circ} \mathrm{C}$ without serious loss of catalyst activity or substrate decomposition. Small amounts of cyclohexene and dicyclohexyl ether were detected by GC/mass spectrometry but their concentrations were low and did not change appreciably over the course of the reaction. Although these results are promising, the high temperatures necessary to achieve reasonable rates are not compatible with currently available membranes. For this reason, long-term use in a membrane is probably not immediately possible, however, tests in membranes will be conducted over short periods to determine the feasibility of such a system.

As discussed above, dehydrogenation of cyclohexanol gives a reaction mixture in which the ketone can be hydrogenated again. However, if pure cyclohexanone or 1:3 cyclohexanone/cyclohexanol mixtures are used with the same $\mathrm{RhCl}_{3} / \mathrm{SnCl}_{2} / \mathrm{LiCl}$ catalyst concentration, hydrogenation occurs extremely slowly and is not the major reaction pathway. A product that has been identified is 2-(cyclohexylidene)cyclohexanone, formed by dimerization and dehydration (eq. 10). The route to this product is unknown at this time but it<smiles>O=C1CCCCC1CCCO</smiles> 
also forms under a nitrogen atmosphere. $\mathrm{CO}_{2}$ and a trace of $\mathrm{CO}$ are detected in the gas phase $\left(\mathrm{H}_{2}\right.$ or $\mathrm{N}_{2}$ atmosphere). These gases are also detected in the attempted hydrogenation of 2-octanone. A control run without $\mathrm{RhCl}_{3}$ but containing $\mathrm{SnCl}_{2}$ and $\mathrm{LiCl}$ in cyclohexanone also generated $\mathrm{CO}_{2}$ and a trace of $\mathrm{CO}$. $\mathrm{CO}_{2}$ may be formed by decarboxylation of a carboxylic acid intermediate. The lack of hydrogenation activity may be due to coordination of ketone which might render the $\mathrm{Rh}$ complex unreactive with $\mathrm{H}_{2}$. This could explain why hydrogenation takes place at very low ketone concentrations but not at higher concentrations.

Subtask B.2. Membrane Attachment and Transport Measurements

A cell used for the membrane separation experiments was designed and constructed. The design is a modification of one used at the National Bureau of Standards [9]. Since our applications require contact with organic solvents, Teflon was used as the construction material. Teflon is chemically resistant and machinable. Overall dimensions are $6 \mathrm{in} . \times 9.25 \mathrm{in}$. with an exposed membrane area of about $200 \mathrm{~cm}^{2}$. Gas dispersion ports were machined into the $3 / 4 \mathrm{in}$. thick blocks. A Teflon mesh is used as the membrane backing and butyl rubber gaskets make the cell leak-tight. Heating is accomplished using heating tape wrapped around the cell and insulating with Kaowool ${ }^{\text {TM }}$. Tests were performed to determine controller setpoints to maintain desired internal temperatures achleved by external control. Nitrogen gas flows through the cell of $50 \mathrm{ml} / \mathrm{min}$ feed and $90 \mathrm{ml} / \mathrm{min}$ sweep did not affect the internal temperature. Gas flows were regulated using calibrated flowmeters. The membrane used was a Teflon-based anion exchange membrane obtained from RAI Research Corporation. The hydroxide counterion in this membrane was replaced with chloride by contacting the membrane with a concentrated aqueous solution of $\mathrm{NaCl}$ followed by several water rinses. The dried membrane was 
then 'wetted' with either pure cyclohexanol or a solution of the $\mathrm{RhCl}_{3} / \mathrm{SnCl}_{2}$ ' $\mathrm{LiCl}$ catalyst solution in cyclohexanol which had been previously activated by heating to $150^{\circ} \mathrm{C}$ for $24 \mathrm{~h}$. The membrane was treated with the catalyst solution and placed in the cell under a $\mathrm{N}_{2}$ atmosphere in a glove bag. Flows of 50 $\mathrm{ml} / \mathrm{min} \mathrm{H}_{2}$ feed and $50 \mathrm{ml} / \mathrm{min} \mathrm{N}_{2}$ sweep were used in tests. The membrane with cyclohexanol was heated to $50^{\circ}, 100^{\circ}, 128^{\circ}, 137^{\circ}$, and $149^{\circ} \mathrm{C}$ and $\mathrm{H}_{2}$ transport measured by gas chromatography. $H_{2}$ transport increased with increasing temperatures and the membrane maintained its integrity throughout the experiment. The membrane with the catalyst solution was tested at $149^{\circ}$ and $128^{\circ} \mathrm{C}$ with results virtually identical to the runs with cyclohexanol. This may be because the membrane did not appear to be actually wetted by either solution but rather a film of solution over the membrane was formed.

Tests with a Celgard ${ }^{T M}$ membrane were also inconclusive. This membrane is wetted by cyclohexanol. However, the membrane could not be kept wet at $150^{\circ} \mathrm{C}$ with flows of $50 \mathrm{ml} / \mathrm{min} \mathrm{N}_{2}$ sweep and $50 \mathrm{ml} / \mathrm{min}_{2}$ feed through the cell. 


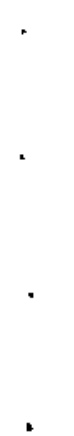




\section{CONCLUSIONS}

In our continuing effort to develop new agents for selective gas separation, a series of complexes of the type $R u(C O)_{2} L_{3}$ ( $L$ Is a phosphine or phosphite) have been prepared. These complexes show a wide range of reactivity with $H_{2}$. When $L$ is $P C y_{3}$, the reaction is irreversible, forming $\mathrm{RuH}_{2}(\mathrm{CO})_{2}(\mathrm{PCy})_{2}$. Hydrides are not formed when $L$ is $\mathrm{PPh}_{2}(\mathrm{a} 1 \mathrm{y} 1), \operatorname{PPh}(\mathrm{a} 1 \mathrm{lyl})_{2}$, $\mathrm{PPh}_{2}(\mathrm{OMe}), \mathrm{PPh}(\mathrm{OMe})_{2}, \mathrm{P}(\mathrm{OMe})_{3}$, and $\mathrm{P}(\mathrm{OPh})_{3}$. Complexes that reversibly react with $\mathrm{H}_{2}$ are those containing $\mathrm{PPh}_{3}, \mathrm{P}(\mathrm{p}-\text { tol })_{3}, \mathrm{P}\left(\mathrm{p}-\mathrm{MeOC}_{6} \mathrm{H}_{4}\right)_{3}$, and $\mathrm{PPh}_{2} \mathrm{Py}$. The complexes containing the first three of these ligands show very similar properties; the reaction with $\mathrm{H}_{2}$ is favorable, but removal of hydrogen from the hydride products is relatively difficult. Previous work with $\mathrm{RuH}_{2}(\mathrm{CO})_{2}\left(\mathrm{PPh}_{3}\right)_{2}$ indicated that with a stoichiometric amount of $\mathrm{PPh}_{3}$, over 7 hours at $65^{\circ} \mathrm{C}$ is required to release the bound $\mathrm{H}_{2}$ and that the reaction is not clean. $\mathrm{Ru}(\mathrm{CO})_{2}\left(\mathrm{PPh}_{2} \mathrm{py}\right)_{3}$ binds $\mathrm{H}_{2}$ quickly and also releases it cleanly within 10 minutes under mild heating. This complex shows a $2: 1$ selectivity for $\mathrm{H}_{2}$ binding over $\mathrm{CO}$ when exposed to a $1: 1 \mathrm{H}_{2} / \mathrm{CO}$ mixture.

The kinetics of $\mathrm{H}_{2}$ binding by $\mathrm{Ru}(\mathrm{CO})_{2}\left(\mathrm{PPh}_{2} \mathrm{Py}\right)_{3}$ were investigated. The results indicate a probable two-step mechanism involving initial phosphine dissociation followed by $\mathrm{H}_{2}$ addition. This type of mechanism was also found for gas binding to $\mathrm{Ru}(\mathrm{CO})_{2}\left(\mathrm{PPh}_{3}\right)_{3}$. Phosphine dissociation appears to be rate limiting in both cases. The equilibrium constant of 350 for $\mathrm{H}_{2}$ binding by the $\mathrm{PPh}_{2} \mathrm{Py}$ complex indicates that $\mathrm{H}_{2}$ is released much more easily than the $\mathrm{PPh}_{3}$ complex $\left(K=10^{4}-10^{5}\right)$. The $\mathrm{PPh}_{2}$ py complex could be of value as a $\mathrm{H}_{2}-$ separation agent in a dual column or membrane application.

The hydrogenation of ketones and the dehydrogenation of alcohols by a $\mathrm{RhCl}_{3} / \mathrm{SnCl}_{2} / \mathrm{LiCl}$ catalyst were studied. Catalysis of the equilibrium between an alcohol and the corresponding ketone and $\mathrm{H}_{2}$ could be utilized within a 
membrane for selective $\mathrm{H}_{2}$ separation. The relatively nonvolatile alcohols cyclohexanol and 2-octane were rapidly dehydrogenated at $150^{\circ} \mathrm{C}$ liberating $\mathrm{H}_{2}$. $\mathrm{H}_{2}$ evolution continued until an equilibrium was established. Increasing the gas-phase $\mathrm{H}_{2}$ concentration over the solution at equilibrium results in $\mathrm{H}_{2}$ uptake caused by hydrogenation of the ketone. With cyclohexanol, three dehydrogenation/hydrogenation cycles at $150^{\circ} \mathrm{C}$ over the course of one week were carried out with no appreciable catalyst deactivation or side reactions. Although the cyclohexanol system possesses good characteristics its applicability in the membrane separation of $\mathrm{H}_{2}$ could not be shown by our initial tests. The major problem encountered was in maintaining a wetted membrane at $150^{\circ} \mathrm{C}$. Since a temperature of $150^{\circ} \mathrm{C}$ appears to give reasonable rates an even less volatile alcohol than those studied is necessary. 


\section{FUTURE DIRECTIONS}

Hydrogen is expected to play an increasingly important role in the future as a chemical feedstock and as an energy carrier. Hydrogen currently is produced primarily by steam hydrocarbon reforming of natural gas. However, as the price of natural gas feedstocks increases as they are projected to, the use of other feedstocks, such as coal, will become increasingly competitive. In addition, efficient methods to separate $\mathrm{H}_{2}$ from coal gasification streams will be very important.

The Pacific Northwest Laboratory (PNL) has been involved for some time in the development of procedures to specifically separate gases using coordination complexes. Research in the past has focused on hydrogen and c0 separation. A palladium dimer $\operatorname{Pd}_{2} X_{2}$ (dppm) 2 is selective for $\mathrm{CO}$ and a ruthenium complex Ru(CO) ${ }_{2}\left(\mathrm{PPh}_{2} \mathrm{py}\right)_{3}$ shows a 2:1 preference for $\mathrm{H}_{2}$ over $\mathrm{CO}$. The ultimate end is to develop complexes suftable for use in membrane systems.

While the cost of facilitated transport membrane systems competes favorably with other separation techniques, advances in selectivity and permeability using cheaper materials will make their use more compelling. Specificity for $\mathrm{H}_{2}$ in the presence of $\mathrm{CO}$ is not always possible using coordination complexes. Our experience suggests that complexes which bind hydrogen also bind $\mathrm{CO}$ and oxygen. This nonspecificity is due to the very active nature of the metal center that is necessary to coordinate hydrogen. In order to increase the specificity for hydrogen, coordinatively saturated, dimeric systems that react by metal-metal bond cleavage are sought. Such a system is represented by the cyclopentadienylchromium tricarbonyl dimer, $\left[\mathrm{CpCr}(\mathrm{CO})_{3}\right]_{2}$, where $C P$ is the cyclopentadienyl group. Research at PNL has shown that quantitative hydrogen uptake occurs at $10 \mathrm{~atm}$ and $25^{\circ} \mathrm{C}$. The hydride loses $\mathrm{H}_{2}$ to regenerate the dimer at $80^{\circ} \mathrm{C}$. The reversible reaction is shown below: 


$$
\left[\mathrm{CpCr}(\mathrm{CO})_{3}\right]_{2}+\mathrm{H}_{2} \rightleftharpoons 2 \mathrm{CpCr}(\mathrm{CO})_{3} \mathrm{H}
$$

Future work is directed toward determination of the dependence of the equilibrium constant on temperature. The uptake of $\mathrm{H}_{2}$ by the chromium complex could be improved by substitution of a carbonyl ligand by an alkylisocyanide. The cost to prepare the chromium complex is projected to be about eight times less than the palladium complex and 80 times less than the ruthenium complex. 


\section{GLOSSARY}

The abbreviations for ligands and complexes used in this report are shown below with their chemical nomenclature.

\begin{tabular}{|c|c|}
\hline $\operatorname{thf}$ & tetrahydrofuran \\
\hline dma & $\mathrm{N}, \mathrm{N}$-dimethylacetamide \\
\hline py & pyridyl \\
\hline p-tol & para-toly 1 \\
\hline $\mathrm{PPh}_{3}$ & triphenylphosphine \\
\hline $\mathrm{P}\left(\mathrm{p}-\mathrm{CH}_{3} \mathrm{C}_{6} \mathrm{H}_{4}\right)_{3}$ & tri (para-tolyl)phosphine \\
\hline$P\left(p-C l C_{6} H_{4}\right)_{3}$ & tri (para-chlorophenyl)phosphine \\
\hline $\mathrm{P}\left(\mathrm{p}-\mathrm{MeOC}_{6} \mathrm{H}_{4}\right)_{3}$ & trianisylphosphine \\
\hline $\mathrm{PBu}_{3}$ & tributylphosphine \\
\hline $\mathrm{PCy}_{3}$ & tricyctohexylphosphine \\
\hline $\mathrm{P}(\mathrm{OMe})_{3}$ & trimethylphosphite \\
\hline $\mathrm{P}(\mathrm{OPh})_{3}$ & triphenyiphosphite \\
\hline $\mathrm{PPh}_{2}(\mathrm{a} \mid \mathrm{y} 1)$ & diphenylallylphosphine \\
\hline $\operatorname{PPh}(\mathrm{a} \mid \mathrm{y} 1)_{2}$ & phenyldiallylphosphine \\
\hline $\mathrm{PPhCy}_{2}$ & phenyldicyclohexylphosphine \\
\hline $\mathrm{PPh}_{2} \mathrm{py}$ & diphenylpyridylphosphine \\
\hline $\mathrm{PPh}(\mathrm{OMe})_{2}$ & phenyldimethoxyphosphine \\
\hline $\mathrm{PPh}_{2} \mathrm{Cl}$ & diphenylchlorophosphine \\
\hline $\mathrm{PPh}\left(\mathrm{C}_{6} \mathrm{H}_{4} \mathrm{NMe}_{2}\right) \mathrm{Cl}$ & phenyl (para-(dimethylamino)phenyl)chlorophosphine \\
\hline $\mathrm{PPh}_{2}\left(\mathrm{C}_{6} \mathrm{H}_{4} \mathrm{NMe}_{2}\right)$ & diphenyl (para-(dimethylamino)phenyl)phosphine \\
\hline $\operatorname{PPh}\left(\mathrm{C}_{6} \mathrm{H}_{4} \mathrm{NMe}_{2}\right)_{2}$ & phenyldi (para-(dimethylamino)phenyl)phosphine \\
\hline dppm & bis(diphenylphosphino) methane \\
\hline
\end{tabular}




\begin{tabular}{|c|c|}
\hline $\mathrm{Pd}_{2}(\mathrm{dppm}) 2_{2}$ & $\begin{array}{l}\text { diha lobis[ } \mu \text {-bis (diphenylphosphino) methane]- } \\
\text { dipalladium (Pd-Pd) }\end{array}$ \\
\hline $\mathrm{RhCl}_{6}^{3-}$ & hexachlororhodate anion \\
\hline $\mathrm{RuCl}_{2}\left(\mathrm{PPh}_{3}\right)_{3}$ & dichlorotris (triphenylphosphine) ruthenium \\
\hline$\left[\mathrm{RuCl}_{2}(\mathrm{CO})_{3}\right]_{2}$ & dichlorotricarbonyl ruthenium dimer \\
\hline $\mathrm{RuCl}_{2}(\mathrm{CO})_{2}(\text { thf })_{2}$ & dichlorodicarbonylbis (tetrahydrofuran) ruthenium \\
\hline $\mathrm{RuCl}_{2}(\mathrm{CO})_{2}\left(\mathrm{PPh}_{3}\right)_{2}$ & dichlorodicarbonylbis (triphenylphosphine) ruthenium \\
\hline $\mathrm{RuCl}_{2}(\mathrm{CO})_{2}\left(\mathrm{P}(\mathrm{p}-\mathrm{tol})_{3}\right)_{2}$ & dichlorodicarbonylbis (tri (p-tolyl)phosphine) ruthenium \\
\hline $\mathrm{Ru}(\mathrm{CO})_{2}\left(\mathrm{PPh}_{3}\right)_{3}$ & dicarbonyltris (triphenylphosphine) ruthenium \\
\hline $\mathrm{Ru}(\mathrm{CO})_{2}\left(\mathrm{PPh}_{2} \mathrm{Py}\right)_{3}$ & dicarbonyltris (diphenylpyridylphosphine) ruthenium \\
\hline $\mathrm{RuH}_{2}(\mathrm{CO})_{2}\left(\mathrm{PPh}_{3}\right)_{2}$ & dihydridodicarbonylbis (tripheny]phosphine) ruthenium \\
\hline $\mathrm{RuH}_{2}(\mathrm{CO})_{2}\left(\mathrm{PPh}_{2} \mathrm{Py}\right)_{2}$ & $\begin{array}{l}\text { dihydridodicarbonylbis (diphenylpyridylphosphine) - } \\
\text { ruthenium }\end{array}$ \\
\hline $\mathrm{RuH}_{2}(\mathrm{CO})_{2}\left(\mathrm{PCy}_{3}\right)_{2}$ & $\begin{array}{l}\text { dihydridodicarbonylbis (tricyclohexylphosphine) - } \\
\text { ruthenium }\end{array}$ \\
\hline 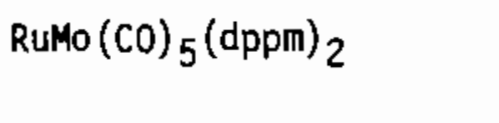 & $\begin{array}{l}\text { pentacarbonylbis ( } \mu \text {-bis (diphenylphosphino) methane) - } \\
\text { ruthernium molybdenum }\end{array}$ \\
\hline $\operatorname{RuMo}(\mathrm{CO})_{6}(\mathrm{dppm})_{2}$ & $\begin{array}{l}\text { hexacarbonylbis ( } \mu \text {-bis (diphenylphosphino) methane) - } \\
\text { ruthenium molybdenum }\end{array}$ \\
\hline $\mathrm{RuMO}(\mathrm{H})_{2}(\mathrm{CO})_{5}(\mathrm{dppm})_{2}$ & $\begin{array}{l}\text { dihydridopentacarbonylbis ( } \mu \text {-bis (diphenylphosphino) - } \\
\text { methane) ruthenium molybdenum }\end{array}$ \\
\hline $\mathrm{RuH}_{2}(\mathrm{dppm})_{2}$ & dihydridobis (bis (diphenylphosphino) methane) ruthenium \\
\hline $\mathrm{Ru}(\mathrm{COD})(\mathrm{COT})$ & cyclooctadienecyclooctatetraeneruthenium \\
\hline $\operatorname{Mo}(\mathrm{CO})_{6}$ & hexacarbonyl \\
\hline
\end{tabular}




\section{EXPERIMENTAL}

All work reported below was performed under inert atmosphere conditions. Ligand Exchange Reactions with $\left.\mathrm{Ru}(\mathrm{CO})_{2} \mathrm{(PPh}_{3}\right)_{3}$

The following procedure is typical of the method used to exchange $\mathrm{PPh}_{3}$ in $\mathrm{Ru}(\mathrm{CO})_{2}\left(\mathrm{PPh}_{3}\right)_{3}$ with $\mathrm{P}(\mathrm{OMe})_{3}, \mathrm{P}\left(\mathrm{P}-\mathrm{CH}_{3} \mathrm{C}_{6} \mathrm{H}_{4}\right)_{3}, \mathrm{P}($ cyclohexyl) 3 , and $\mathrm{P}\left(\mathrm{p}-\mathrm{ClC}_{6} \mathrm{H}_{4}\right)_{3}$. $\mathrm{Ru}(\mathrm{CO})_{2}\left(\mathrm{PPh}_{3}\right)_{3}(500 \mathrm{mg}, 0.53 \mathrm{mmol})$ in $20 \mathrm{ml}$ thf was refluxed $0.5 \mathrm{~h}$ with at least a 10 -fold excess of phosphine. The volume was reduced to $10 \mathrm{ml}$, hexane added, and cooled to $-60^{\circ} \mathrm{C}$. Solid products obtained from the reactions with $\mathrm{P}\left(\mathrm{p}-\mathrm{CH}_{3} \mathrm{C}_{6} \mathrm{H}_{4}\right)_{3}$ and $\mathrm{PCy}_{3}$ were filtered and dried. 0ils were obtained from the other preparations. Ligand Exchange Reactions with $\mathrm{RuCl}_{2}\left(\mathrm{PPh}_{3}\right)_{3}$

In a typical experiment, $\mathrm{RuCl}_{2}\left(\mathrm{PPh}_{3}\right)_{3}(500 \mathrm{mg}, 0.52 \mathrm{mmol})$ in $100 \mathrm{ml}$ hexane was refluxed with at least a 10 -fold excess of either $P(\mathrm{p}-\mathrm{tol})_{3}, \mathrm{PCy}_{3}$, $\mathrm{P}(\mathrm{OMe})_{3}$, or $\mathrm{P}(\mathrm{OPh})_{3}$ for 17 hours. Solutions of the ruthenium reaction mixtures were purged with $C 0 .{ }^{31} P$ NMR indicated new materials were obtained from $\mathrm{P}(\mathrm{p}-\mathrm{tol})_{3}$ and $\mathrm{P}(\mathrm{OPh})_{3}$ while reactions with $\mathrm{PCy}_{3}$ and $\mathrm{P}(\mathrm{OMe})_{3}$ were unsuccessful. $\underline{\left[\mathrm{RuCl}_{2}(\mathrm{CO})_{3}\right]_{2}}$

$\mathrm{RuCl}_{3} \cdot 3 \mathrm{H}_{2} \mathrm{O}(10 \mathrm{~g})$ in $500 \mathrm{ml} \mathrm{MeOH}$ was placed in a $1 \mathrm{~L}$ autoclave. The autoclave was purged for $20 \mathrm{~min}$. with $\mathrm{CO}$, pressurized to $10 \mathrm{~atm}$, and heated to $60-65^{\circ} \mathrm{C}$ for $30 \mathrm{~h}$. After venting, the solution was filtered and evaporated to dryness to give a green-yellow solid $(9 \mathrm{~g}, 72 \%)$. $\underline{\mathrm{RuCl}_{2}(\mathrm{CO})_{2}\left[\mathrm{P}\left(\mathrm{C}_{6} \mathrm{H}_{4} \mathrm{CH}_{3}\right)_{3}\right]_{2}}$

To $0.2 \mathrm{~g}, 8.4 \mathrm{mmol}$ of $\left[\mathrm{RuCl}_{2}(\mathrm{CO})_{3}\right]_{2}$ dissolved in $30 \mathrm{~mL}$ of $\mathrm{CH}_{2} \mathrm{Cl}_{2}$ was added $0.53 \mathrm{~g}, 1.76 \mathrm{mmol}$ of $\mathrm{P}\left(\mathrm{C}_{6} \mathrm{H}_{4} \mathrm{CH}_{3}\right)_{3}$. The solution was refluxed for 2 
hours. The light yellow solution was reduced to $10 \mathrm{~mL}$ and diTuted with ether. The white precipitate was filtered and vacuum dired, $0.6 \mathrm{~g}$ for $91 \%$ yield. $\mathrm{Ru}(\mathrm{H})_{2}(\mathrm{CO})_{2}\left[\mathrm{P}\left(\mathrm{C}_{6} \mathrm{H}_{4} \mathrm{CH}_{3}\right)_{2}\right.$

Both of $0.66 \mathrm{~g}, 0.79 \mathrm{mmol}$ of $\mathrm{RuCl}_{2}(\mathrm{CO})_{2}\left[\mathrm{P}\left(\mathrm{C}_{6} \mathrm{H}_{4} \mathrm{CH}_{3}\right)_{3}\right] 2$ and $0.48 \mathrm{~g}, 1.58$ mmol of $\mathrm{P}\left(\mathrm{C}_{6} \mathrm{H}_{4} \mathrm{CH}_{3}\right)_{3}$ were suspended in $150 \mathrm{~mL}$ of thf. An excess amount of sodium amalgam was added and the resulting mixture was stirred for 48 hours. The sodium amalgam was removed by decantation and filtration through celite. The clear orange solution was reduced to $10 \mathrm{~mL}$ and diluted with $150 \mathrm{~mL}$ of hexane. Hydrogen gas was bubbled through the solution. A white precipitate slowly formed and was filtered, $0.4 \mathrm{Bg}$. The ${ }^{1} \mathrm{H}-\mathrm{nmr}$ spectrum in $\mathrm{CDCl}_{3}$ indicated a triplet at $-4.47 \mathrm{ppm}$ with a coupling constant of $\mathrm{J}_{\mathrm{P}_{-H}}=19.4 \mathrm{~Hz}$. The ${ }^{31} \mathrm{P}-\mathrm{nmr}\left(\mathrm{PPh}_{3}\right)$ spectrum gave a singlet at $75.26 \mathrm{ppm}$. $\mathrm{RuCl}_{2}(\mathrm{CO})_{2}\left(\mathrm{PCy}_{3}\right)_{2}$

The dimer $\left[\mathrm{RuCl}_{2}(\mathrm{CO})_{3}\right]_{2}$ was refluxed in thf to give $0.4 \mathrm{~g}, 1.07$ mmol of $\mathrm{RuCl}_{2}(\mathrm{CO})_{2}$ (thf $)_{2}$. This was combined with $0.69 \mathrm{~g}, 2.42$ mmol of tricyclohexylphosphine in $40 \mathrm{~mL}$ of $\mathrm{CH}_{2} \mathrm{Cl}_{2}$ and refluxed for 2 hours. The yellow solution was reduced to $10 \mathrm{~mL}$ and diluted with ether. The yellow product was filtered and dried, $0.64 \mathrm{~g}$ for $75 \%$ yield. $\mathrm{Ru}(\mathrm{H})_{2}(\mathrm{CO})_{2}\left(\mathrm{PCy}_{3}\right)_{2}$

The preparation was similar to that used for $\mathrm{Ru}(\mathrm{H})_{2}(\mathrm{CO})_{2}\left[\mathrm{P}\left(\mathrm{C}_{6} \mathrm{H}_{4} \mathrm{CH}_{3}\right)_{3}\right]_{2}$. The ${ }^{1} \mathrm{H}$-nmr spectrum in $\mathrm{CD}_{2} \mathrm{Cl}_{2}$ indicated a triplet at $-8.51 \mathrm{ppm}$ with $\mathrm{J}_{\mathrm{P}-\mathrm{H}}=$ $22.56 \mathrm{~Hz}$. The ${ }^{31} \mathrm{P}-n \pi m r\left(\mathrm{PPh}_{3}\right)$ spectrum gave a singlet at $44.75 \mathrm{ppm}$. $\mathrm{RuCl}_{2}(\mathrm{CO})_{2}\left[\mathrm{P}\left(\mathrm{C}_{6} \mathrm{H}_{4} \mathrm{OCH}_{3}\right)_{3}\right]_{2}$

Both $0.25 \mathrm{~g}, 0.67 \mathrm{mmol}$ of $\mathrm{RuCl}_{2}(\mathrm{CO})_{2}$ (thf) ${ }_{2}$ and $0.53 \mathrm{~g}, 1.51 \mathrm{mmol}$ of trianisylphosphine were dissolved in $30 \mathrm{~mL}$ of $\mathrm{CH}_{2} \mathrm{Cl}_{2}$ and refluxed for 1 hour. 
The solution volume was reduced to $10 \mathrm{~mL}$ and pentane was added to precipitate the white product, $0.58 \mathrm{~g}$ for $92 \%$.

$\mathrm{Ru}(\mathrm{H})_{2}(\mathrm{CO})_{2}\left[\mathrm{P}\left(\mathrm{C}_{6} \mathrm{H}_{4} \mathrm{OCH}_{3}\right)_{3}\right]_{2}$

To $0.4 \mathrm{~g}, 0.43$ mाmol of $\mathrm{RuCl}_{2}(\mathrm{CO})_{2}\left[\mathrm{P}\left(\mathrm{C}_{6} \mathrm{H}_{4} \mathrm{OCH}_{3}\right)_{3}\right]_{2}$ and $0.19 \mathrm{~g}, 0.54$ mाthol of trianisylphosphine suspended in $150 \mathrm{~mL}$ of thf was added an excess of sodium amalgam. The reaction was performed in a manner similar to those noted above. The white hydride product gave a ${ }^{31} \mathrm{P}-\mathrm{nmr}\left(\mathrm{PPh}_{3}\right)$ spectrum with a singlet at 55.82 .

$\mathrm{RuH}_{2}(\mathrm{CO})_{2}\left(\mathrm{PPh}_{2} \mathrm{Py}\right)_{2}$

$\mathrm{Ru}(\mathrm{CO})_{2}\left(\mathrm{PPh}_{2} \mathrm{Py}\right)_{3}$ (200 $\left.\mathrm{mg} ; 0.2112 \mathrm{mmlol}\right)$ in $20 \mathrm{ml}$ thf was saturated with 1 atm. $\mathrm{H}_{2}$ for $1 \mathrm{~h}$. The volume of the solution was reduced to $10 \mathrm{ml}$ under vacuum and the solution again exposed to $\mathrm{H}_{2}$. Hexane $(150 \mathrm{ml})$, saturated with hydrogen, was added to precipttate the brown-yellow product which was filtered and dried. Yield: $147 \mathrm{mg} ; 70 \%, 1_{H}$ NMR: $\delta-7.14 \mathrm{ppm}$, triplet, $\mathrm{J}_{\mathrm{P}-\mathrm{H}}=24 \mathrm{hz} .{ }^{31_{P}}$ NMR: $662.83 \mathrm{ppm}$ (with respect to $\mathrm{PPh}_{3}$ ).

$\underline{R u(C O D)(C O T)}$

RuCl $_{3} \cdot 3 \mathrm{H}_{2} \mathrm{O}(0.7 \mathrm{~g})$ was dissolved in $20 \mathrm{ml}$ degassed EtOH. Cyclooctadiene (COD; $17 \mathrm{ml}$ ) was added and the solution refluxed for $15-20 \mathrm{~min}$. Zn dust (7.0 g) was added slowly and the resulting mixture refluxed for $3 \mathrm{~h}$ and filtered. The resulting yellow solution was evacuated to dryness overnight and the residue extracted with $100 \mathrm{ml}$ pentane. The mixture was filtered through neutral alumina, reduced to $5 \mathrm{ml}$ and cooled to $-80^{\circ} \mathrm{C}$. Yellow needles formed and were filtered cold.

$\mathrm{RuH}_{2}(\mathrm{dppm})_{2}$

$\mathrm{Ru}(\mathrm{COD})(\mathrm{COT})(300 \mathrm{mg})$ and $\mathrm{dppm}(750 \mathrm{mg})$ were dissolved in $20 \mathrm{ml}$ toluene. $\mathrm{H}_{2}$ was bubbled through the solution for $1 \mathrm{~h}$ and the solution sealed under $\mathrm{H}_{2}$ 
for $15 \mathrm{~h}$. Hexane $(50 \mathrm{ml})$ was added to precipitate a pale yellow solid which was filtered and vacuum dried. RuMo $(\mathrm{CO})_{6}(\mathrm{dppm})_{2}$

$\mathrm{RuH}_{2}(\mathrm{dppm})_{2}(300 \mathrm{mg}, 0.344 \mathrm{mmol})$ and $\mathrm{Mo}_{0}(\mathrm{CO})_{6}(90.8 \mathrm{mg}, 0.344 \mathrm{mmol})$ were heated to $80^{\circ} \mathrm{C}$ in $10 \mathrm{ml}$ toluene for $3.5 \mathrm{~h}$. The pale yellow suspension dissolved and a red solid formed. The solution was cooled to $-80^{\circ} \mathrm{C}$ and filtered under nitrogen. The precipitate was vacuum dried. $\mathrm{PPh}\left(\mathrm{C}_{6} \mathrm{H}_{4} \mathrm{NMe}_{2}\right) \mathrm{Cl}$

To $\mathrm{Mg}(2.17 \mathrm{~g}, 0.0893 \mathrm{moles})$ in $10 \mathrm{ml}$ thf was added dropwise a solution of $\mathrm{Me}_{2} \mathrm{NC}_{6} \mathrm{H}_{4} \mathrm{Br}(7.40 \mathrm{~g}, 0.0370$ moles $)$ in $30 \mathrm{ml}$ thf. After stirring $1 \mathrm{~h}$ the resulting solution was added dropwise over a $1.5 \mathrm{~h}$ period to $\mathrm{PhPCl}_{2}(5.0 \mathrm{ml}$, $3.69 \times 10^{-2}$ moles) dissolved in $10 \mathrm{ml}$ thf and cooled to $0^{\circ} \mathrm{C}$. The solution was reduced in volume to $10 \mathrm{ml}$ and a total of $20 \mathrm{ml} \mathrm{Et} \mathrm{t}_{2} \mathrm{O}$ added to precipitate a white solid which was filtered and washed with $\mathrm{CH}_{2} \mathrm{Cl}_{2}$. The solvent was removed from the filtrate and a minimum amount of thf was added to dissolve the residue. A yellow solid that precipitated on standing was filtered and washed with thf and vacuum dried $(3.68 \mathrm{~g})$. $\operatorname{PPh}\left(\mathrm{C}_{6} \mathrm{H}_{4} \mathrm{NMe}_{2}\right)_{2}$

To $\mathrm{Mg}(0.23 \mathrm{~g})$ in $10 \mathrm{ml} \mathrm{Et} \mathrm{t}_{2} \mathrm{O}$ was added dropwise Ph8r $(0.4 \mathrm{ml}, 5.6 \mathrm{mmol})$ dissolved in $5 \mathrm{ml} \mathrm{Et} \mathrm{t}_{2} \mathrm{O}$. After stirring for ca. $1 \mathrm{~h}$ the solution was added slowly to a suspension of $\mathrm{PPh}\left(\mathrm{C}_{6} \mathrm{H}_{4} \mathrm{NMe}_{2}\right) \mathrm{Cl}(0.50 \mathrm{~g}, 1.9 \mathrm{mmol})$ in $10 \mathrm{ml}$ thf. The yellow solid dissolved immediately to give a colorless solution. The reaction was quenched with saturated aqueous $\mathrm{NH}_{4} \mathrm{Cl}$ and extracted with benzene. The benzene layer was dried with $\mathrm{MgSO}_{4}$ and reduced in volume to ca. $1 \mathrm{ml}$. Addition of $80 \mathrm{ml}$ EtOH and cooling resulted in the precipitation of a white solid which was filtered, washed, and vacuum dried $(0.16 \mathrm{~g})$, mp $154-155^{\circ} \mathrm{C}$. 


\section{REFERENCES}

1. D. A. Nelson, M. A. Lilga, S. E. Lyke, R. T. Hallen, "Separation of Gas Mixtures by Supported Complexes," Final Report (PNL-5375) to DOE/METC.

2. B. Chaudret, S. Sabo, XII International Conference on Organometallic Chemistry, Italy, 1985.

3. S. Trippett, D. M. Walker, J. Chem. Soc. (1961)2130.

4. D. J. Peterson, J. Organometal. Chem. 8(1967) 199.

5. H. B. Charman, Nature, 212(1966) 278.

6. H. B. Charman, J. Chem. Soc. (B) (1967) 629 .

7. H. B. Charman, J. Chem. Soc. (B) (1970) 584 .

8. S. Shinoda, H. Moriyama, Y. Kise, Y. Saito, J. Chem. Soc. Chem. Commun. (1978) 348 .

9. B. R. Bateman, J. D. Way, K. M. Larson, Separation Science and Technology, 19(1984)21.1 


\section{•}




\section{ACKNOWLEDGMENTS}

The authors wish to thank Drs. Brian James and Chung-Li Lee of the University of British Columbia for their efforts with the investigation of phosphine exchange reactions. We would also like to thank Erik Meier for his contributions as a NORCUS summer student at Pacific Northwest Laboratory. 
PNL -5733

UC-90

\section{DISTRIBUTION}

No. of

Copies

\section{OFFSITE}

5 Dr. Hsiao-Ya L. Lai

Advanced Gasification Section

Coal Research Management Center

Morgantown Energy Technology

Center

P. 0. Box 880

Collins Ferry Road

Morgantown, WV 26505

30 DOE Technical. Information Center

Dr. Brian R. James

The University of British Columbia

Department of Chemistry 2075 Wesbrook Place

Vancouver, B.C., Canada V6T 1 Y6

J. Douglas Way

National Bureau of Standards

Center for Chemical Engineering

Chemical Engineering Science

Division, 773.10

325 Broadway

Boulder, Co 80303
No. of

Copies

Marvin I. Singer

Office of Fossil Energy

Department of Energy

washington, DC 20545

Leonard M. Naphtali

Office of Fossil Energy

Department of Energy

Washington, DC 20545

ONSITE

DOE Richland Operations Office

J. J. Sutey

24 Pacific Northwest Laboratory

R. S. Kemper

P. C. Walkup

D. A. Nelson (14)

M. A. Lilga

Technical Information (5)

Publishing Coordinator (2) 